\title{
Exploring the Implementation of Weblog-Based Flipped Classroom in Teaching Civics: Is It Feasible and Effective?
}

\author{
Yuliyatno \\ A Graduate student of Educational Technology Program of Universitas PGRI Adi \\ Buana, Surabaya, Indonesia, tabrizyyuli@gmail.com
}

\section{Mustaji}

The Lecturer of Graduate Program of Universitas Negeri Surabaya, Surabaya, Indonesia,mustaji@unesa.ac.id

\section{Nurmida Catherine Sitompul}

The Lecturer of Graduate Program of Universitas PGRI Adi Buana, Surabaya, Indonesia, nurmida.catherine.s@unipasby.ac.id

Although there are some studies revealing the effectiveness of the implementation of flipped classroom, but a study investigating the feasibility and effectiveness of weblog integration during the implementation of flipped classroom for teaching civics is still scarce. This study aimed at investigating the feasibility and the effectiveness of the implementation of weblog-based flipped classroom model. This study used the combined approach (Creswell, 2012) of qualitative and quantitative. The qualitative approach was in the form of a case study design. Meanwhile, the quantitative approach was in the form of experimental with preand-post test design. The participants of this study were 42 students of Social Class of Islamic Senior High School. The data were gathered through semi-structured interview, questionnaire, and test, i.e. pre-and-post test. The qualitative data were analyzed descriptively; and the quantitative data were analyzed by using paired sample t-test formula. The results revealed that the implementation of weblogbased flipped classroom is feasible and applicable. Furthermore, it has been statistically proven that it is effective to teach civics indicated by the raise of students' achievement in civics. This study implies that innovation of technologybased learning has great influence in students' achievement and this should be taken into account by the related parties.

Keywords: weblog, flipped classroom, civics, feasibility, technology-based learning

Citation: Yuliyatno, Mustaji, \& Sitompul, N. C. (2019). Exploring the Implementation of WeblogBased Flipped Classroom in Teaching Civics: Is It Feasible and Effective? International Journal of Instruction, 12(4), 239-250. https://doi.org/10.29333/iji.2019.12415a 


\section{INTRODUCTION}

In this 4.0 technological era, the development of technology influences almost all of parts of humans' life. Education is one of the parts that is mostly influenced by the technology. The advances of internet and communications technology make teachers easily offer dynamic multi-media educational resources and the capability to support both content and assessment between instructors and learners (Levy, 2010). A new paradigm shift has taken place in education with the advent of a model of teaching known as the flipped classroom. The flipped classroom is a model of teaching in which a student's homework is the traditional lecture viewed outside of class on a vodcast. Then class time is spent on inquiry-based learning which would include what would traditionally be viewed as a student's homework assignment (Overmyer, 2014). The flipped classroom model encompasses any use of using Internet technology to leverage the learning in a classroom, so that a teacher can spend more time interacting with students instead of lecturing (Bergmann \& Sams, 2012a). This is most commonly done by creating videos that students view outside of class time. It is called the flipped class model because the whole classroom/homework paradigm is 'flipped'. In its simplest terms, what used to be class work (the lecture) is done at home via teacher-created videos and what used to be homework (assigned problems) is done in class.

Weblog is one of e-learning media that can be used as a teaching aid in flipped classroom model. A weblog or blog can be described as an online journal with one or many contributors. Besides straight text and hyperlinks, many blogs incorporate other forms of media, such as images and video. Blogs differ from traditional websites and provide many advantages over traditional sites (Duffy \&Bruns, 2006), including: (1) easy creation of new pages, since new data is entered into a blog usually through a simple form and then submitted with the blogger (or person adding the entry to the blog website) updating the blog with little or no technical background, blogs have thus become the novice's web authoring tool; (2) filtering of content for various blog entries, for example by date, category, author, or one of many other attributes. Most blog platforms allow the blog administrator to invite and add other authors, whose permissions and access are easily managed; (3) providing a personal writing space that is easy to use, sharable, and automatically archived; (4) ability to link and inter-link to form learning communities; (5) opportunity to serve as a digital portfolio of students' assignments and achievements; and (6) extensions into fully featured content management systems. Through weblog, teachers could put many kinds of learning materials including video to be accessed by students. Another term of weblog is 'blogging', a contraction of the term 'web logging'. It is described as a form of micropublishing. Weblog has become firmly established as a web based communications tool (Williams \& Jacobs, 2004). The weblog phenomenon has evolved from its early origin as a medium for the publication of simple, online personal diaries, to the latest disruptive technology, which has the capacity to engage people in collaborative activity, knowledge sharing, reflection and debate (Hiler, 2003).

Civics education is a crucial and basic part of social sciences with a particular reference to the fact of socialization. As a consequence, to provide mutual solidarity, sharing, love, respect, friendship even brotherhood, sense of national belonging, and identity 
among the citizens of countries, what the governing bodies or administrators are seriously required to do is to apply these crucial civics tool (Solihatin \&Öztürk, 2014). Civics education is a kind of cement which is very essential for socialization and unity of any nation of any country. Particularly for those countries, which have plural structure with a diverse racial and cultural background, they certainly need civics education. Indonesia is a country that has very colorful structure in terms of race, language, religion, and culture with a huge population and surface area which consists of over 15,000 islands (Solihatin \&Öztürk, 2014). Due to the importance of civics education, teachers should be creative and innovative in teaching civics to the students. Civics education should be taught in a manner that stresses the constant link between knowledge and practice.

There are a number of studies investigating the implementation of flipped classroom in teaching and learning process (see Baker, 2000; Bergmann \& Sams, 2012a; Bergmann \& Sams, 2012b; Berret, 2012; Brame, 2013; and Bishop \& Verleger, 2013). Besides, there are also a number of studies dealing with the use of weblog in teaching and learning (see Embrey, 2002; Lamshed, Berry, \& Armstrong, 2002; Oravec, 2002; Stiller \& Philleo, 2003; Ferdig \& Trammell, 2004; Williams \& Jacobs, 2004; Duffy \& Bruns, 2006; Richardson, 2006). Dealing with civics lesson, there are also some studies focusing on civics lesson (see Ichilov, 2003; Solihatin \&Öztürk, 2014). However, from those previous studies, there is still no study investigating the implementation of weblog-based flipped classroom in teaching civivs lesson in Indonesian context. Therefore, this study was conducted to fulfill the gap by investigating the feasibility and the effectiveness of weblog-based flipped classroom in teaching civics in Indonesia.

Based on the background above, this study was focused to achieve the following research objectives:

1. To analyze the feasibility of the implementation of weblog-based flipped classroom in teaching civics, and

2. To investigate the effectiveness of the implementation of weblog-based flipped classroom in teaching civics.

\section{METHOD}

\section{Research Design}

This study employed a combined approach (Creswell, 2012) of qualitative and quantitative. This combined approach was considered the most relevant for this study since the objectives of this study were (1) analyzing the feasibility of the implementation of weblog-based flipped classroom in teaching civics, and (2) investigating the effectiveness of the implementation of weblog-based flipped classroom in teaching civics. To answer the first objective, a qualitative approach in the form of a case study design was employed. Meanwhile, to answer the second objective, a quantitative approach in the form of experimental with pre-and-post test design was employed.

\section{Participants}

This study was conducted at the twelfth-graders of social class of an Islamic Senior High School (Madrasah Aliyah Negeri 2 Bojonegoro) in East Java, Indonesia at the odd 
semester of 2018/2019 academic year. The total number of the participants was 42 students. This purposive sampling technique was applied by following the principle of criterion and intensity sampling. As stated by Rohmah, at.al (2019) Purposive sampling was done in order to maximize the information from the participants. All of the students were placed in one class. During the data collection using interview, not all students were involved. The interviewees were chosen purposively based on those having high and moderate score of civics. Besides, those who were interviewed must the students who have strong willingness to be involved in this study. After the participants were chosen purposively, 10 out of 42 students were chosen for interview. Meanwhile, for questionnaire distribution and experimental design, the 42 students were involved altogether.

\section{Data Collection Technique Semi-structured interview}

As it was mentioned previously, this study used a combined approach. As a consequence, there was also different data collection techniques used in this study. To collect the qualitative data, a semi-structured interview was used. This technique was done in order to get the comprehensive data dealing with the students' perceptions and opinions of the implementation of weblog-based flipped classroom in civics lesson. This interview was conducted to 10 out of 42 students who had been chosen purposively. This interview was conducted after the students were treated by using weblog-based flipped classroom in civics lesson.

\section{Questionnaire}

The second instrument used to collect data was questionnaire. This questionnaire was in the form of close-ended questions with five options following the Likert Scale. This questionnaire was used to check whether or not the students' interview answers were valid. This questionnaire was distributed to all of 42 students who had been treated by using weblog-based flipped classroom in civics lesson.

\section{Test (pre-and-post test)}

To collect the quantitative data, pre-and-post test were employed to 42 students. The pre-test was given before the students were treated by using weblog-based flipped classroom in civics lesson. On the contrary, the post-test was given after the students were treated by using weblog-based flipped classroom in civics lesson for 6 meetings. The results of pre-and-post test, then, were compared for analysis.

\section{Data Validation Technique}

\section{Qualitative data}

To guarantee that the data yielded from this study was valid, the researchers used a triangulation technique. The process of triangulation was conducted by comparing and analyzing the results of interview and questionnaire simultaneously. According to Patton (2002), methods of triangulation often involves comparing and integrating data collected through some kind of qualitative methods with data collected through some kind of quantitative methods. Therefore, in order to test the consistency of the data obtained qualitatively from interview and questionnaire were selected according to their relevance to the research questions (see Creswell \& Miller, 2000; Creswell, 2012). 


\section{Quantitative data}

To guarantee that the quantitative data yielded from the test, the researchers first tried the test instrument out to other samples. Since the test was in the form of multiple choice, the results of try out, then, were analyzed its items for validity and reliability. The validity of test item was done using point-biserial correlation coefficient formula and the reliability of the test instrument was done using $K R 21$. By doing so, the quantitative data yielded from the test instrument were also valid and reliable.

\section{Data Analysis Technique}

As there were two kinds of data in this study, the data analysis techniques were also different between the qualitative data and quantitative data. The qualitative data yielded from interview was analyzed descriptively following the steps of qualitative data analysis proposed by Creswell (2012). It was analyzed by examining the "bottom-up" approach to analysis. The researchers first collect data and then prepare it for data analysis. This analysis initially consists of developing a general sense of the data, and then coding description and themes about the central phenomenon. In this study, coding schemes were used to gain a more detailed perspective about what was occurring based on the purpose of the study. These coding schemes helped to analyze the transcripts of the participants. Besides, descriptive statistics were also used to analyze quantitative data gained from the questionnaires (Ghufron\&Ermawati, 2018). Further, the quantitative data yielded from pre-and-post test were analyzed by using paired sample ttest. The means scores were compared and analyzed. However, before the data of preand-post test were analyzed, its normality and homogeneity were tested. The normality test was done by using Lielifors formula and the homogeneity test was done by using Bartlett formula. After the data were concluded that they were in normal distribution and homogeneous, then, the t-test was implemented.

\section{Procedures}

One class of the twelfth-graders of social class consisting of 42 students were given a pre-test dealing with their knowledge of civics lesson. After that, the students were taught by using flipped classroom model with the aids of weblog for 6 meetings. The flipped classroom is a pedagogy whereby online lectures take place outside class, and the conventional classroom is used for active problem solving. The materials dealing with civics lesson was provided in the weblog for 6 meetings including some quiz to check the students' understanding. During face-to-face meeting, the students were given problems dealing with the materials to be solved. The solution of the problems have been prepared and provided in the weblog which they can access outside the class. This process was done in 6 meetings. After the 6 meetings were over, the students were given a post-test about their understanding of civics lesson. The questions of pre-test and posttest were different, but the indicators remained the same. Besides, it was also chosen 10 students to be interviewed and all students were given a questionnaire of feasibility of the weblog-based flipped classroom. All data yielded from the test, interview, and questionnaire were analyzed. 


\section{FINDINGS AND DISCUSSION}

\section{The Feasibility of Weblog-Based Flipped Classroom in Teaching Civics Lesson}

The first objective of this study was to analyze the feasibility of the implementation of weblog-based flipped classroom in teaching civics lesson. To get the data dealing with this objective, semi-structured interview and questionnaire were used. From the results of semi-structured interview, it can be inferred that weblogs-based flipped classroom is feasible to be implemented in teaching civics lesson. Besides, it also motivates the students to learn civics, since commonly, the students are reluctant to learn civics. They perceived that civics is a boring lesson and also not challenging. But their perceptions are changed after the teacher implemented weblog-based flipped classroom. The following is the excerpt of the interview with the S1 (student 1):

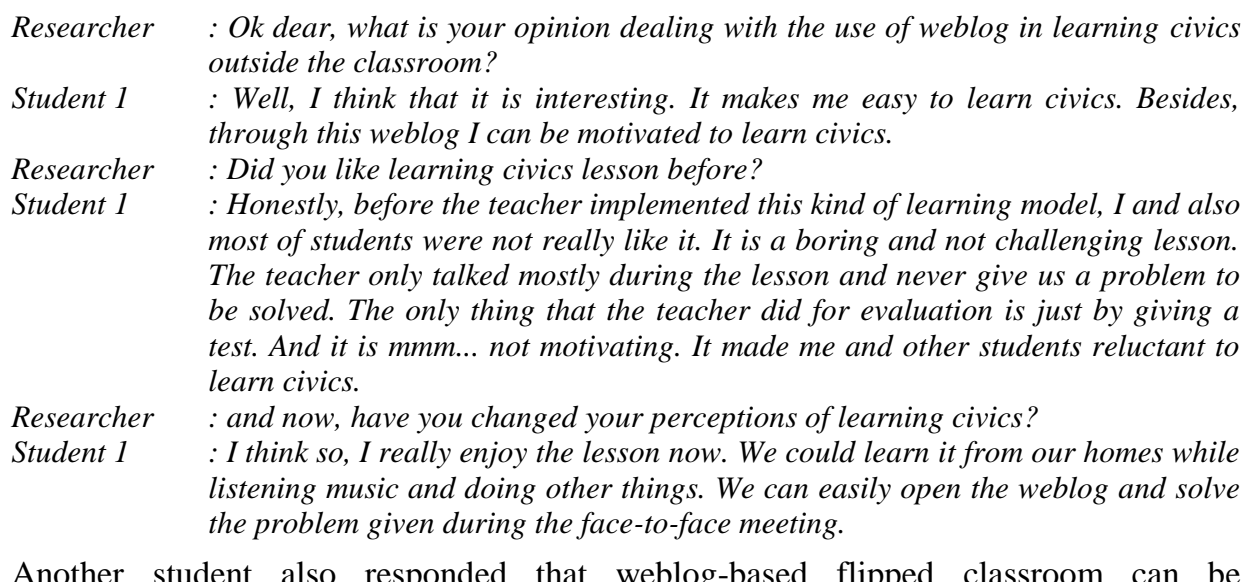
implemented in teaching civics. She argued that it is easy to do. She can open the weblog whenever and wherever she wants outside the classroom. She can easily access it through her smartphone. But a small problem will arise when she does not have the internet access. If it happens, she usually will top up the balance of her smartphone. The following is the excerpt of the interview.

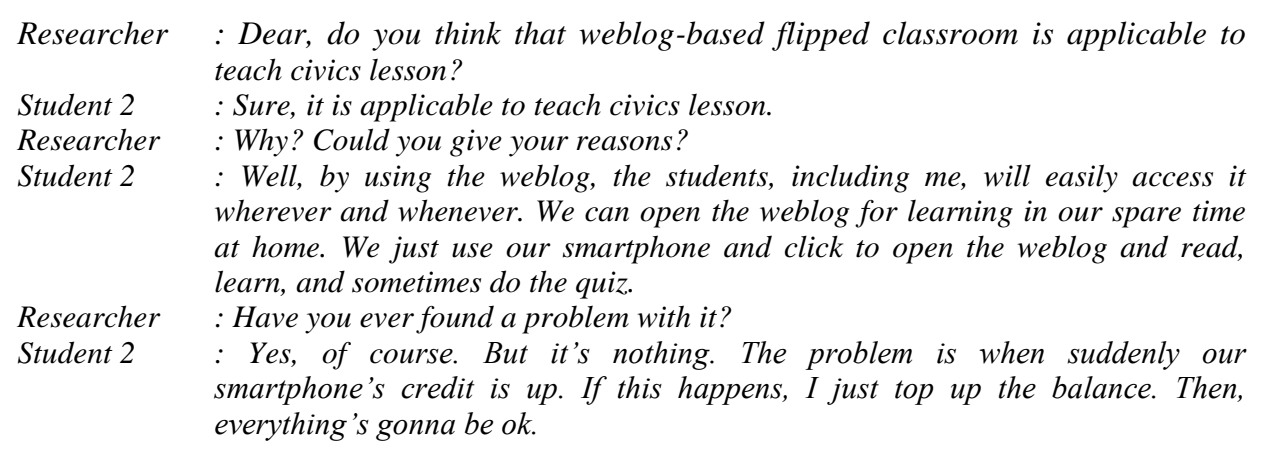

The similar response was given by student 5 . He told that after the use of weblog in 
civics lesson, he became more motivated in learning civics. It is because during the faceto-face meeting, the teacher gives the students a challenge in the form of problems that must be solved the students. Therefore, the face-to-face meeting was focused on discussion. Then, the solutions of the problems are provided both explicitly and implicitly in the weblog. Those activities make the students more motivated and the weblog really help them to solve the problems given. Moreover, the weblog is accessible 24 hours. The following is the excerpt of the interview.

Researcher : What is your comment dealing with the implementation of weblog-based flipped classroom in teaching civics?

Student $5 \quad$ : Hmm, I think it really motivates me, not only me, I think all students are also motivated.

Researcher : Why is it motivating?

Student $5 \quad$ :It's because during the face-to-face meeting, the teacher gives us a challenge in the form of problems that must be solved. So, during the face-to-face meeting, we focus on discussion. Meanwhile, the solutions of the problems are provided in weblog explicitly and implicitly. The weblog is accessible wherever and whenever as far as we have internet connection.

Researcher : Do you think that this learning model is feasible and applicable for teaching civics?

Student $2 \quad$ :Yes, of course. It feasible and applicable. All materials are provided in the weblog which we can access outside the classroom. Moreover, it is also accessible from smartphone. All of us have the smartphone.

Another data collection technique used to answer the first objective was questionnaire. This questionnaire was in the form of close-ended questions with five options following the Likert Scale. This questionnaire was used to check whether or not the students' interview answers were valid. This questionnaire was distributed to all of 42 students who had been treated by using weblog-based flipped classroom in civics lesson. The questionnaire has 10 statements. The statements consist of 7 positive statements and 3 negative statements. The following are the statements:

Table 1

The Questionnaire of Feasibility of the Implementation of Weblog-based Flipped Classroom

\begin{tabular}{|c|c|c|c|c|c|c|}
\hline \multirow[b]{2}{*}{ No. } & \multirow[b]{2}{*}{ Statements } & \multicolumn{5}{|c|}{ Answers } \\
\hline & & $\begin{array}{l}\text { Strongly } \\
\text { Agree }\end{array}$ & $\begin{array}{l}\text { Strongly } \\
\text { Agree }\end{array}$ & $\begin{array}{l}\text { Strongly } \\
\text { Agree }\end{array}$ & $\begin{array}{l}\text { Strongly } \\
\text { Agree }\end{array}$ & $\begin{array}{l}\text { Strongly } \\
\text { Agree }\end{array}$ \\
\hline 1 & Learning civics through weblog is motivating & & & & & \\
\hline 2 & Learning civics through flipped classroom is motivating & & & & & \\
\hline 3 & Learning civics using weblog-based flipped classroom is easy & & & & & \\
\hline 4 & The weblog is accessible wherever and whenever & & & & & \\
\hline 5 & $\begin{array}{l}\text { If there is a problem dealing with the weblog, it can be easily } \\
\text { solved }\end{array}$ & & & & & \\
\hline 6 & $\begin{array}{l}\text { Weblog-based flipped classroom can be implemented in teaching } \\
\text { civics }\end{array}$ & & & & & \\
\hline 7 & $\begin{array}{l}\text { The problems given by the teacher during the face-to-face } \\
\text { meeting are not soluble }\end{array}$ & & & & & \\
\hline 8 & The weblog does not provide comprehensive materials of civics & & & & & \\
\hline 9 & $\begin{array}{l}\text { The flipped classroom is difficult to be implemented in civics } \\
\text { lesson }\end{array}$ & & & & & \\
\hline 10 & $\begin{array}{l}\text { The weblog-based flipped classroom is an interesting learning } \\
\text { model instead of traditional teaching and learning }\end{array}$ & & & & & \\
\hline
\end{tabular}


From the questionnaire above, the results can be seen in the following figure.

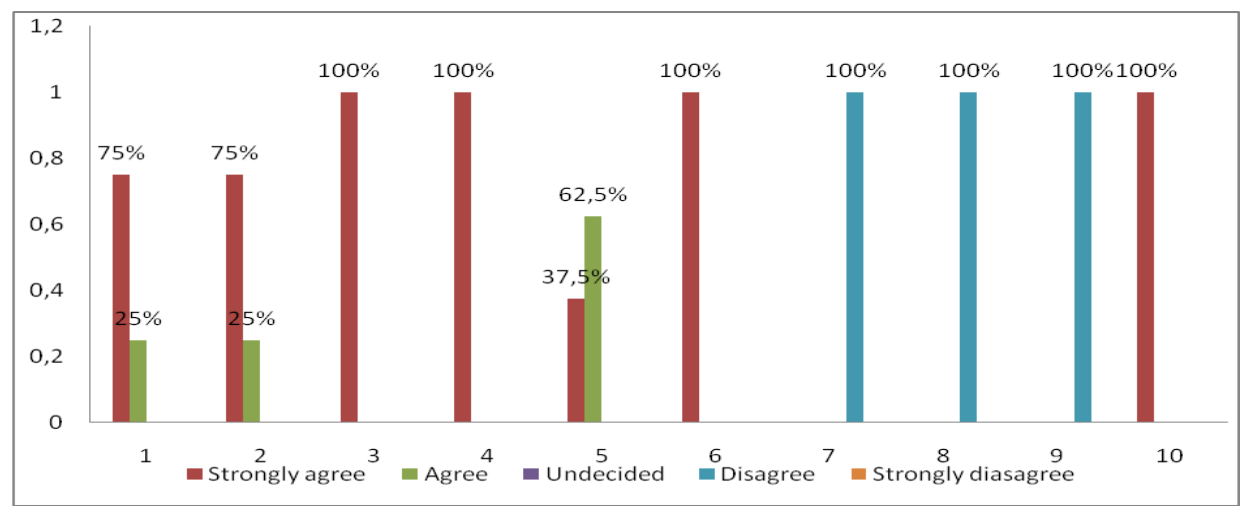

Figure 1

The Results of Questionnaire Distribution

From Figure1, it can be seen that most of the respondents responded positively towards the implementation of weblog-based flipped classroom in Civics lesson. They asserted that learning civics through weblog-based flipped classroom is motivating, easy, and interesting.

After clarifying the results of the questionnaire with the interview, it can be inferred that it is feasible to implement the weblog-based flipped classroom in teaching civics lesson. Although the flipped classroom is a new learning model, the students could easily adapt it in their teaching and learning process. This is in line with the study of Joanne \& Lateef (2014) in which they state that the flipped classroom, although it is a relatively new model of practice in Asia, appears to be gaining momentum and is well-received. Holmes, et. al. (2015) state that flipped classroom is considered a natural fit to the teaching of social work clinical practice skills; these techniques were designed to recognize students' diverse learning styles and to promote hands-on application of practice skills in classroom and field settings. The use of weblog in teaching and learning process also gives benefits to students. Duffy \& Bruns (2006) state that within the structure of a weblog, students can demonstrate critical thinking, take creative risks, and make sophisticated use of language and design elements. In doing so, the students acquire creative, critical, communicative, and collaborative skills that may be useful to them in both scholarly and professional contexts.

\section{The Effectiveness of Weblog-Based Flipped Classroom in Teaching Civics Lesson}

The second objective of this study was to investigate the effectiveness of weblog-based flipped classroom in teaching civics lesson. To answer this objective, an experimental with pre-test and post-test design was used.

\section{Pre-test results}

The data yielded from pre-test was first tested its normality by using Lilliefors formula. The following is summary of Lilliefors test. 
Table 2

The Summary of Normality Test of Pre-Test Data

\begin{tabular}{llllllll}
\hline Group & $\begin{array}{l}\text { Number of } \\
\text { Group }\end{array}$ & Mean & St.Dev. & $\mathrm{L}_{\mathrm{o}}$ & $\mathrm{L}_{\mathrm{t}(0.05)}$ & $\begin{array}{l}\text { Test } \\
\text { Result }\end{array}$ & Conclusion \\
\hline Pre-Test & 42 & 72.45 & 6.23 & 0.0719 & 0.1367 & $\mathrm{~L}_{0}<\mathrm{L}_{\mathrm{t}}$ & Normal \\
\hline
\end{tabular}

After the data was identified in normal distribution, the homogeneity test was done by using Bartlett test. Based on the result of homogeneity testing, it was gained that the value of $\chi_{0}{ }^{2}$ is 2.14 while the table value of $\chi_{t}{ }^{2}$ for $\mathrm{df}=1$ at the level of significance $\alpha=0.05$ is 3.841. Because $\chi_{0}^{2}$ is lower than $\chi_{t}^{2}$, it can be concluded that the data are homogeneous.

\section{Post-test results}

The data yielded from post-test was first tested its normality by using Lilliefors formula. The following is summary of Lilliefors test.

Table 3

The Summary of Normality Test of Post-Test Data

\begin{tabular}{llllllll}
\hline Group & $\begin{array}{l}\text { Number of } \\
\text { Group }\end{array}$ & Mean & St.Dev. & $\mathrm{L}_{\mathrm{o}}$ & $\mathrm{L}_{\mathrm{t}(0.05)}$ & Test Result & Conclusion \\
\hline Post-Test & 42 & 77.88 & 8.23 & 0.0725 & 0.1367 & $\mathrm{~L}_{0}<\mathrm{L}_{\mathrm{t}}$ & Normal \\
\hline
\end{tabular}

After the data was identified in normal distribution, the homogeneity test was done by using Bartlett test. Based on the result of homogeneity testing, it was gained that the value of $\chi_{0}^{2}$ is 2.19 while the table value of $\chi_{t}^{2}$ for $\mathrm{df}=1$ at the level of significance $\alpha=0.05$ is 3.841 . Because $\chi_{0}^{2}$ is lower than $\chi_{t}^{2}$, it can be concluded that the data are homogeneous.

\section{Paired-sample t-test}

To come to the conclusion whether or not there is a significant difference of students' achievement in civics lesson before and after the treatment, the means score of pre-test and post-test were compared and analyzed by using paired-sample t-test. The results of the analysis are shown in table 4.

Table 4

The Summary of Paired-Sample T-Test

\begin{tabular}{llllllll}
\hline Group & $\begin{array}{l}\text { Number } \\
\text { of Group }\end{array}$ & Mean & St.Dev. & $\begin{array}{l}\mid \mathrm{t}_{\mathrm{o}} \\
\text { (Absolute } \\
\text { Score) }\end{array}$ & $\mathrm{t}_{\mathrm{t}(0.05 ; 41)}$ & $\begin{array}{l}\text { Test } \\
\text { Result }\end{array}$ & Conclusion \\
\hline $\begin{array}{l}\text { Pre-Test } \\
\text { Post-Test }\end{array}$ & 42 & $\begin{array}{c}72.45 \\
77.88\end{array}$ & $\begin{array}{c}6.23 \\
8.23\end{array}$ & -5.368788 & 2.019541 & $\mathrm{t}_{\mathrm{o}}>\mathrm{t}_{\mathrm{t}}$ & Significant \\
\hline
\end{tabular}

From Table 4 above, it is clearly seen that the absolute score of $t_{o}$ is higher than $t_{t}\left(t_{o}>t_{t}\right)$. It means that there is a significant difference of the students' achievement in civics lesson before and after the treatment. The students' score significantly increase after the weblog-based flipped classroom was implemented in teaching civics lesson. Therefore, it is concluded that the implementation of weblog-based flipped classroom in civics lesson is effective.

The flipped classroom model provides many benefits for instruction (Overmyer, 2014). Proponents of the flipped model argue that it is how a teacher uses the newly freed 
class-time that is most important (Bergmann \& Sams, 2012a). The most important feature of the flipped class model is to increase teacher-to-student and student-to-student interaction during class time. Teachers who use the flipped classroom model asserted that the best benefit of flipped classroom is that they have some one-on-one contact with every student during every class period (Moore, Gillett, \& Steele, 2014). The flipped classroom model may also have benefits in reducing anxiety in difficult, content heavy courses (Strauss, 2013). Further, Overmyer (2014) argues that a flipped model does not change the amount of face-to-face time that a student spends in a classroom when compared to a traditional classroom. For the flipped classroom to have possible benefits, the goal of online videos, weblog, or other media is not to replace in-class learning, but to instead supplement and enhance the learning and, face-to-face time should promote deeper, inquiry-based learning. Besides, the use of weblog integrated with flipped classroom also has some benefits for education such as: promoting critical and analytical thinking, promoting creative, intuitive and associational thinking (creative and associational thinking in relation to blogs being used as brainstorming tool and also as a resource for interlinking, commenting on interlinked ideas), promoting analogical thinking, increasing access and exposure to quality information, combining solitary and social interaction (Richardson, 2006). Weblogs can be used across academic disciplines and become a viable tool for technologists in education (Huffaker, 2005). Further, Du and Wagner (2007) explain that the use of weblogs in teaching and learning is considered an important predictor of learning outcome since weblogs can be used as a knowledge construction tool and a social learning medium. From those explanation of the benefits of flipped classroom and weblog media, it is no wonder that this study also has the same positive results. It is indicated that the students who are taught by using weblog-based flipped classroom have a significant increase of achievement in civics lesson.

\section{CONCLUSION AND IMPLICATIONS}

From the results of the study, it can be directly stated that weblog-based flipped classroom model is feasible to be implemented in teaching civics; and further, it has also been statistically proven that weblog-based flipped classroom model is effective to be implemented in teaching civics. The results of this study imply that innovation of technology-based learning has great influence in students' achievement and this should be taken into account by the teachers. This study also has some limitations, i.e. this study was only done in a small setting and it is merely focused on the use of weblog media to teach civics lesson. The future studies may investigate further about the effect of flipped classroom in a wider research setting and with various accessible e-learning media.

\section{REFERENCES}

Baker, J. W. (2000). The "classroom flip": Using web course management tools to become the guide by the side. Paper presented at the 11th International Conference on College Teaching and Learning, Jacksonville, FL.

Bergmann, J., \& Sams, A. (2012a). Flip your classroom: Reach every student in every class every day. Washington, D.C: International Society for Technology in Education. 
Bergmann, J., \& Sams, A. (2012b). How the flipped classroom is radically transforming learning. The Daily Riff. Retrieved from: http://www.thedailyriff.com/articles/how-theflipped-classroom-is-radicallytransforming-learning-536.php.

Berrett, D. (2012). How 'flipping' the classroom can improve the traditional lecture. The Chronicle of Higher Education, 58(21) 16-18.

Bishop, J., \& Verleger, M. (2013). The flipped classroom: A survey of the research. Paper presented at the 120th ASEE Annual Conference \& Exposition. American Society for Engineering Education. Atlanta.

Brame, C. (2013). Flipping the classroom. Vanderbilt University Center for Teaching. Retrieved from: http://cft.vanderbilt.edu/guides-sub-pages/flipping-theclassroom/.

Creswell, J. W. (2012). Educational research: Planning, conducting and evaluating quantitative and qualitative research. Boston: Pearson Education Inc.

Creswell, J. W., \& Miller, D. M. (2000). Determining validity in qualitative inquiry. Theory Into Practice, 39(3), 124-130.

Du, H. S., \& Wagner, C. (2007) Learning with weblogs: Enhancing cognitive and social knowledge construction. IEEE Transactions on Professional Communication, 50(1), 116, doi: 10.1109/TPC.2006.890848.

Duffy, P., \& Bruns, A. (2006). The use of blogs, wikis and RSS in education: A conversation of possibilities. In Proceedings Online Learning and Teaching Conference 2006, pp. 31-38, Brisbane.

Embrey, T. (2002). You blog, we blog: A guide to how teacher librarians can use weblogs to build communication and research skills. Teacher Librarian, 30(2), 7-9.

Ferdig, R. E., \& Trammell, K. D. (2004). Content delivery in the 'Blogosphere'. Technological Horizons in Education Journal, 31(7). Retrieved from: http://www.thejournal.com/magazine/vault/articleprintversion.cfm?aid=4677.

Ghufron, M. A., \& Ermawati, S. (2018). The strengths and weaknesses of cooperative learning and problem-based learning in EFL writing class: Teachers and students' perspectives. International Journal of Instruction, 11(4), 657-672. https://doi.org/10.12973/iji.2018.11441a.

Hiler, J. (2003). Blogs as disruptive tech: How weblogs are flying under the radar of the content management giants. Retrieved from: http://www.webcrimson.com/ourstories/blogsdisruptivetech.htm.

Holmes, M. R., Tracy, E. M., Painter, L. L., Oestreich, T., \& Park, H. (2015) Moving from flipcharts to the flipped classroom: Using technology driven teaching methods to promote active learning in foundation and advanced masters social work courses. Clinical Social Work Journal, 43(2), 215-224. https://doi:10.1007/s10615-015-0521-x.

Huffaker, D. (2005). The educated blogger: Using weblogs to promote literacy in the classroom. AACE Journal, 13(2), 91-98. 
Ichilov, O. (2003). Teaching civics in a divided society: The case of Israel. International Studies in Sociology of Education, 13(3), 216-242.

Joanne, C. S. M., \& Lateef, F. (2014). The flipped classroom: Viewpoints in Asian universities. Education in Medicine Journal, 6(4), 20-26. https://doi:10.5959/eimj.v6i4.316.

Lamshed, R., Berry, M., \& Armstrong, L. (2002). Blogs: Personal e-learning spaces. Retrieved from http://www.binaryblue.com.au/docs/blogs.pdf.

Levy, S. (2010) Tabula rasa: Why the new generation of tablet computers changes everything. Wired. 18(4), 75-85.

Moore, A., Gillett, M., \& Steele, M. (2014). Fostering student engagement with the flip. Mathematics Teacher, 107(6), 22-27.

Oravec, J. (2002). Bookmarking the world: Weblog applications in education. Journal of Adolescent and Adult Literacy, 45(7), 616-621.

Overmyer, G. R. (2014). The flipped classroom model for college Algebra: Effects on sudent achievement (Unpublished doctoral dissertation). School of Education, Colorado State University.

Richardson, W. (2006). Blogs, wikis, podcasts, and other powerful web tools for classrooms. Thousand Oaks, CA: Corwin Press.

Rohmah, I.I.T., Saleh, M., Faridi, A., Fitriati, S.W. (2019) Language Assessment Pattern for Primary Education in the Content and Language Integrated Learning (CLIL) Classroom Context, Asian EFL Journal, 21(2.2), 101-123. https://www.elejournals.com/asian-efl-journal/asian-efl-journal-volume-21-issue-2-2march-2019/

Solihatin, E., \& Öztürk, A. (2014). Increasing civics learning achievement by applying cooperative learning: Team game tournament method. Sociology Study, 4(11), 949-954. https://doi:10.17265/2159-5526/2014.11.004.

Stiler, G. M. \& Philleo, T. (2003). Blogging and blogspots: An alternative format for encouraging reflective practice among pre-service teachers. Education, 123(4), 789-797.

Strauss, V. (2013). The flip: Turning a classroom upside down. Washington Post. Retrieved from http://www.washingtonpost.com/pb/local/education/the-flip-turningaclassroom-upside-down/2012/06/03/gJQAYk55BV_story.html.

Williams, J. B., \& Jacobs, J. (2004). Exploring the use of blogs as learning spaces in the higher education sector. Australasian Journal of Educational Technology, 20(2), 232247. 